The Giant Sucking Sound: Did NAFTA Devour the Mexican Peso?

\section{Christopher J. Neely}

$t$ the end of 1993 Mexico was touted as a model for developing countries.

Five years of prudent fiscal and monetary policy had dramatically lowered its budget deficit and inflation rate and the government had privatized many enterprises that were formerly state-owned. To culminate this progress, M exico was preparing to enter into the N orth American Free Trade Agreement (NAFTA) with Canada and the United States. But less than a year later, in December 1994, investors sold their peso assets, the value of the Mexican peso plunged 50 percent against the U.S. Dollar, and M exico was forced to borrow from the International M onetary Fund (IMF) and the United States to get through a financial crisis. In 1995, inflation in M exico soared to 50 percent and real gross domestic product (GDP) fell by 4 percent.

Politicians and commentators like Ross Perot, Pat Buchanan, William Greider, and Robert Kuttner blamed the enactment of NAFTA for the devaluation of the peso and the ensuing economic turmoil in Mexico, with some calling for its renegotiation or even repeal. As the members of NAFTA consider expanding to encompass other Latin American nations, such as Chile, investors and policymakers should understand the link between NAFTA and the peso crisis well. Did NAFTA cause or exacerbate the devaluation of the peso? Or did NAFTA help alleviate some of the consequences of the crisis?
This article examines the relationship between NAFTA and the peso crisis of December 1994. First, the provisions of NAFTA are reviewed, and then the links between NAFTA and the peso crisis are examined. Despite a blizzard of innuendo and intimation that there was an obvious link between the passage of NAFTA and the peso devaluation, NAFTA's critics have not been clear as to what the link actually was. Examination of their arguments and economic theory suggests two possibilities: that NAFTA caused the Mexican authorities to manipulate and prop up the value of the peso for political reasons or that NAFTA's implementation caused capital flows that brought the peso down. Each hypothesis is investigated in turn.

\section{NAFTA}

NAFTA grew out of the U.S.-Canadian Free Trade Agreement of $1988 .{ }^{1}$ It was signed by M exico, Canada, and the United States on December 17, 1992. The legislatures of those countries ratified NAFTA, and the agreement took effect on January 1,1994 . The treaty substantially lowered national barriers to trade and investment in N orth America, giving consumers more choices and lower prices. In addition, the changes began to lower the cost of production and to funnel investment and labor to their most productive uses. Not surprisingly, the costs - real and imagined- of this reall ocation of resources stirred the passions of those opposing the agreement.

The trade provisions of NAFTA were designed to reduce tariffs and nontariff barriers-such as quotas and import licensing-radically over 15 years. Some tariffs were reduced immediately, whereas other reductions will be phased in over a period of 10 years -15 years for certain sensitive sectors, such as agriculture and textiles and apparel.

\footnotetext{
1 See Hufbauer and Schott (1993), Aguilar (1993), or Tomell and Esquivel (1995) for more discussion of NAFTA's provisions.
} 
2 See Tornell and Esquivel (1995). Changes in valueweighted tariff schedules can be misleading, however, because there are also some quantitative restrictions.

3 See Kehoe (1995) for a review of Mexico's recent trade history.

4 The GATT was an international organization to negotiate free trade among its members. It has been superseded by the World Trade Organization (WTO).

${ }^{5}$ Krugman (1993) and Brown, Deardorf and Stern (1992) discuss estimates of the gains from NAFTA.
For the United States and M exico, the trade provisions of NAFTA are expected to have their most important effects on the automobile, textile and apparel, and agricultural sectors. In agriculture, U.S. and M exican quotas were immediately converted into equivalent tariffs and those tariffs will be phased out over 10 to 15 years. As Hufbauer and Schott (1993) note, this is a remarkable achievement given the difficulties encountered by other free trade agreements on agricultural issues.

Given the fierce fight in the United States over the agreement, it is ironic that NAFTA required more substantial changes in Mexican law - both trade and investment law - than it did in U.S. law. Average U.S. tariff levels on M exican goods were al ready quite low-just four percent- on a value-weighted basis, before the introduction of NAFTA. ${ }^{2}$ Mexican tariffs were higher, averaging 10 percent on imports from the United States. Through NAFTA, M exico also committed itself to address other long-standing U.S. concerns, like the protection of intellectual property rights and reform of Mexico's regulation of foreign investment.

NAFTA was the culmination of a significant break with M exico's protectionist past. ${ }^{3}$ Until the 1970 s, Mexico followed a policy of import substitution industrialization that mandated highly protected markets for manufactured goods. In that decade, preliminary reforms in the direction of freer trade were taken. The debt crisis of 1982 reversed that trend; for a short period in 1982-1983, Mexico was one of the most protected economies in the world. During the de la Madrid administration (1982-88), M exico took important steps to move toward more liberal trade. Mexico lowered tariffs and joined the General Agreement on Tariffs and Trade (GATT) in 1986. ${ }^{4}$ Mexico took further unilateral steps toward free trade as part of the Salinas administration's (1988-94) program of economic reform. This period is known as la apertura (the opening).
Despite the impressive achievements of the negotiators in crafting such a farreaching trade agreement, NAFTA's direct economic benefit to the United States will likely be small. One representative estimate of NAFTA's annual benefits to Mexico and the United States arrives at approximately the same figure for each country; ${ }^{5}$ however, this amounts to about 0.3 percent of 1993 U.S. GDP but more than 5.0 percent of M exico's output. Schott (1994), Tornell and Esquivel (1995) and others have argued that the most important aspect of NAFTA's passage for the Mexican economy is that it would cement the other economic reforms in place. Krugman (1993) and Orme (1993) both contend that NAFTA is most important to the United States as a tool of foreign policy, to encourage Mexican economic and political reform.

\section{NAFTA AND THE VALUE OF THE PESO}

This section lays out the case that the peso was kept overvalued because of the politics of NAFTA and then investigates whether this argument is consistent with the facts.

\section{The Case That the Peso's Value Was Artificially Inflated Because of the Politics of NAFTA}

The most common hypothesis linking NAFTA to the peso crisis is that the politics of NAFTA caused the Bank of Mexico to systematically manipulate the value of the peso to increase support for the treaty, both before NAFTA was passed in the United States and during its first year. There are two versions of this hypothesis. The first version suggests that the value of the peso was deliberately manipulated to secure political support for NAFTA and that the devaluation - to obtain a trade advantagewas planned well in advance. The second version is less sinister. It suggests only that the M exican authorities were sensitive to U.S. politics in setting exchange rate policy after NAFTA was passed. The following sections lay out the arguments behind each version of this hypothesis. 


\section{Deliberate Manipulation and Planned Devaluation.}

“... the devaluation of the peso had been planned for more than a year and was openly discussed at the highest levels of the M exican government. It was also widely known in Washington. I discussed it in my testimony before the House Committee on Small Business in March, 1993- eight months before the North American Free Trade Agreement was passed into law."

Ross Perot, Los Angeles Times, January 4, 1995. ${ }^{6}$

\section{Critics like Ross Perot arguethat the} M exican government and the Bank of M exico kept the value of the peso artificially high to increase political support for the treaty in the U nited States by creating a bilateral tradesurplus with M exico. The United States did have a trade surplus with M exico in the early 1990 s. A study by Hufbauer and Schott (1993) was frequently cited by NAFTA proponents to support the questionable notion that the growth of this trade surplus would create 170,000 jobs in the United States. The Clinton administration used these arguments to sell NAFTA to the U.S. Congress primarily as a jobs program, rather than as a trade agreement that would promote greater choiceand lower prices for consumers and greater efficiency in production.

"We will make our case as hard and as well as we can. And, though the fight will be difficult, I deeply believe we will win. And I'd like to tell you why. First of all, because NAFTA means jobs. American jobs, and good-paying American jobs. If I didn't believethat, I wouldn't support this agreement."

President Bill Clinton at the signing of NAFTA Side Agreements on September 14, 1993.

President Clinton even talked about leaving NAFTA after three years if a review of the evidence at that time suggested that the treaty had cost American jobs. So there was considerable pressure to produce evidence that showed that NAFTA would create jobs in the United States.

The Mexican government was not immune to such pressure. In 1993, passage of NAFTA by the U.S. Congress was the main policy concern of the Mexican administration [see Tornell and Esquivel (1995)]. In August of that year, President Salinas even promised to raise the M exican minimum wage to alleviate U.S. fears of cheap M exican labor driving down U.S. wages and taking jobs. Critics charge that because of such political considerations, the Mexican government deliberately kept the peso overvalued throughout 1993 and 1994 and planned the eventual devaluation well in advance.

Sensitivity to U.S. Politics. A more reasonable hypothesis is put forward by Velasco (1995) and others. They suggest only that, after NAFTA was passed, the Mexican authorities were sensitive to the U.S. political situation and may therefore have been more reluctant to permit the peso to depreciate than they would otherwise have been. Specifically, in March 1994, the peso came under speculative pressure in the wake of the assassination of Luis Donaldo Colosio, presidential candidate of the ruling Revolutionary Institutional Party (PRI). At that time, a number of observers warned that the peso was overvalued and that a faster devaluation was warranted. Velasco suggests that because such a course of action threatened to create political problems with the United States, political exigencies may have prevented an earlier, milder correction to the value of the peso that would have avoided the drastic correction of the later crisis.

\section{Evaluating the Case that the Peso's Value was Artificially Inflated Because of the Politics of N AFTA}

Critics argue that NAFTA provided the impetus for the M exican monetary authorities to maintain the value of the peso in

\footnotetext{
${ }^{6}$ See also, columnist Robert Kuttner, January 22, 1995, in the Akron Beacon Journal and author William Greider in Rolling Stone, March 9, 1995.
} 
excess of its equilibrium value. The authorities allegedly knew that the peso was overvalued but gambled that this overvaluation could be maintained long enough to secure NAFTA's passage in the United States. Thus, this hypothesis requires that:

1. The peso was overvalued.

2. The Mexican authorities knew that it was overvalued.

3. The Mexican authorities kept it overvalued to increase or at least maintain support for NAFTA in the United States.

Although it is not possible to test the elements of this hypothesis, they may be examined to see whether they are consistent with the facts. This section argues that though the evidence favors the view that the peso was overvalued, this was not obvious at the time. Further, to the extent that the peso may have been overvalued, the overvaluation was a result of the disinflation strategy of the Mexican authorities, rather than a result of NAFTA.

Nominal and Real Exchange Rates. When discussing the value of the peso, it is important to distinguish between the nominal exchange rate, or the price of a peso in terms of dollars, and the real exchange rate, the price of M exican goods in terms of U.S. goods. This section explains the relationship between prices and exchange rates and why the real exchange rate is the rel evant measure of the proper value of the peso.

Exchange rates and prices are linked through thelaw of one price, which says that identical goods should sell for the same price when expressed in terms of the same currency. ${ }^{7}$ In the case of oil, for example,

$$
p_{\text {oil }}^{\text {U.S. }}(t)=p_{\text {oil }}^{M E X}(t) \times e(t),
$$

where the variable $p_{\text {oil }}^{\text {U.S. }}(t)$ is the price of oil

Barriers to trade, transportation costs, and imperfectly competitive markets may prevent the law of one price from holding. barrel of oil costs $\$ 20$ in the United States and 80 pesos in Mexico, the law of one price predicts the nominal exchange rate will be $\$ 0.25$ per peso. This condition must approximately hold, or people could make money by buying oil in the country where it is cheap and selling it in the country where it is expensive. Such arbitrage would tend to drive the price of oil down in the country where it is expensive and raise the price in the country where it is cheap, until the law of one price approximately holds.

If the law of one price holds for each good in a price index and the weights in the price index are the same for each country, then consumption baskets should also sell for the same price when expressed in the same currency. This is called absolute purchasing power parity (PPP), which can be expressed as follows:

$$
p_{\text {Index }}^{\text {U.S. }}(t)=p_{\text {Index }}^{M E X}(t) \times e(t),
$$

where $p_{\text {Index }}^{\text {U.S. }}(t)$ is a measure of the price level in the United States and $p_{\text {Index }}^{\mathrm{MEX}}(t)$ is the analogous measure for M exico. Of course, because of different patterns of consumption across countries, the presence of nontraded goods and differentiated goods, absolute PPP does not describe the relation of price levels and exchange rates very well.

A less stringent, but more realistic relation is relative PPP. It says that differences in countries' inflation rates should be reflected in changes in the exchange rate, so that

$$
\Delta \mathrm{p}_{\text {Index }}^{\mathrm{U} . \mathrm{S} .}(\mathrm{t})-\Delta \mathrm{p}_{\text {Index }}^{\mathrm{MEX}}(\mathrm{t})=\Delta \mathrm{e}(\mathrm{t}),
$$

where $\Delta$ stands for the percentage change in a variable over time. This equation says that if inflation in M exico exceeds inflation in the United States, the exchange rate will fall to reflect the difference. That is, the peso will depreciate. Why? If Mexican goods become more expensive than U.S. goods, consumers in both the United States and M exico will tend to buy more U.S. goods. This will cause the peso to depreciate until M exican goods are competitive again. 
A strict interpretation of relative PPP says that the real exchange rate, or the price of M exican goods in terms of U.S. goods, should be constant over time. At time $t$, the real exchange rate $(q(t))$ can be expressed as follows:

$$
q(t)=\frac{p_{\text {Index }}^{\text {MEX }}(t) \times e(t)}{p_{\text {Index }}^{u . S . S}(t)} .
$$

For practical purposes, however, relative PPP is interpreted to mean that the real exchange rate should tend to come back to its historical average rather than be constant over time. Empirical studies suggest that this interpretation of relative PPP is useful for thinking about long-run tendencies in exchange rates, especially when inflation rates are high.

Why is the real exchange rate important? A currency has value only because of what it can purchase. The real exchange rate adjusts the nominal value of a currency for its purchasing power and so determines competitiveness in world markets. For example, a rise in the real exchange rate (as defined previously) means that the price of M exican goods in terms of U.S. goods has risen. The price of M exican exports to the United States rises, hurting Mexican exporters, but imports from the United States become cheaper to Mexican consumers. Therefore the relevant measure of the value of the peso is the value of the real exchange rate.

Was the Peso Overvalued? Armed with the concept of the real exchange rate, it is still difficult to determine whether the peso was correctly valued because the real exchange rate changes over time. In the case of a pegged exchange rate system like M exico's, a real exchange rateis functionally overvalued or undervalued if the nominal exchange rateis likely to beforced to change quickly. That is, the real exchange rate should be compatible with the commitment to the pegged nominal exchange rate.

Relative PPP suggests a practical measure of whether the current real exchange rate is likely to be consistent with the peg: whether it is in line with historical values
Figure 1

Index of the Real Exchange Rate (WPI)

Mean $=100$

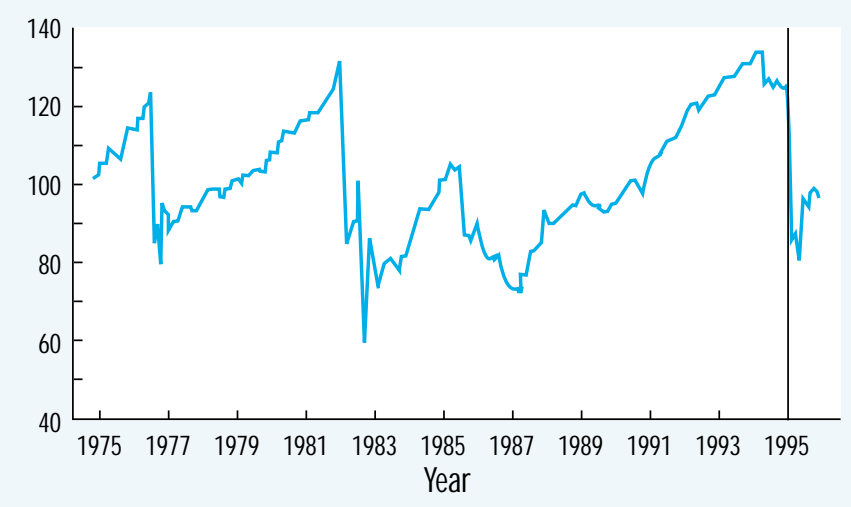

of the real exchange rate. If the Mexican inflation rate minus the U.S. inflation rate exceeds the rate of depreciation of the peso- that is, if

$$
\Delta \mathrm{p}_{\text {Index }}^{\mathrm{MEX}}(\mathrm{t})-\Delta \mathrm{p}_{\text {Index }}^{\mathrm{U.SS}}(\mathrm{t})>-\Delta \mathrm{e}(\mathrm{t}),
$$

- then the real exchange rate rises and Mexican goods became more expensive in terms of U.S. goods; the peso becomes overvalued. Historical measures of the correct value of the real exchange rate are imperfect, though. The proper value of the real exchange rate can change over time because of changes in productivity, preferences, legal capital controls, or other factors. These changes are usually slow, however, leaving historical measures useful.

Respected economists like Dornbusch and Werner (1994) argued during 1993 and 1994 that the peso was overvalued because an index of the real exchange rate, as measured by the Wholesale Price Index (W PI), was high by historical standards. As illustrated in Figure 1, this index rose steadily from a level of 70 in 1987 to a peak of about 130 at the end of 1993. By this measure, Mexican goods had become almost twice as expensive in terms of U.S. goods from 1987 through 1993 and the real value of the peso was 30 percent higher than its historical average from 1975 through 1993. Dornbusch and Werner cautioned early in 1994 that 


\section{Figure 2}

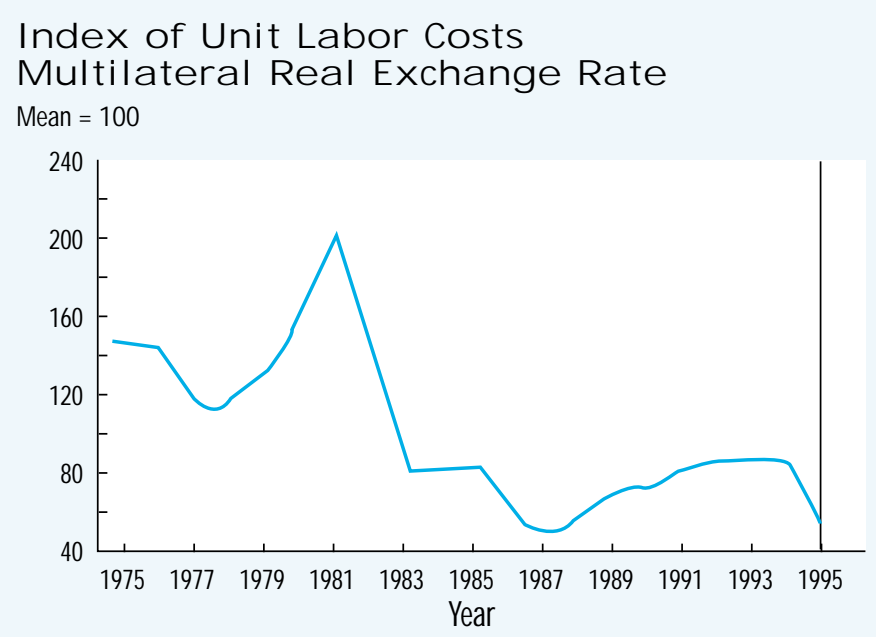

Figure 3

International Reserves

Billions of U.S. Dollars

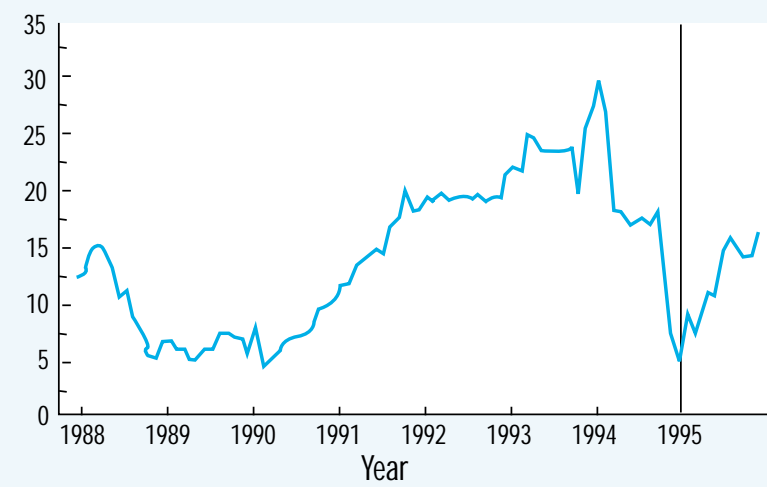

${ }^{8}$ Data for the multilateral real exchange rate were taken from Gil-Diaz and Carstens (1995).
Carstens (1995) argue that unit labor costs are a better way to compute real exchange rates because they more closely reflect the relative cost of production in M exico and abroad. Further, the real value of the peso for Mexico's trade depended not only on its value vs. the dollar, but also on its value vs. M exico's other trading partners, and therefore they suggest that multilateral measure of the real exchange rate is more appropriate. Figure 2 shows that, by the beginning of 1994, the multilateral effective real exchange rate index, as measured by unit labor costs, had also risen substantially-about 60 percent-since 1987 but was still as low as it had ever been before $1986 .{ }^{8}$ In fact, it was still slightly below its historical average for the period 1975-94. Thus Gil-Diaz and Carstens argued that this historical measure did not show the real exchange rate to be overvalued.

Second, because the proper value of the real exchange rate can change over time because of productivity changes and other factors, the Mexican authorities disagreed with Dornbusch and Werner about the relevance of historical measures. They asserted that NAFTA and other economic reforms had raised productivity and had increased the correct (equilibrium) value of the real exchange rate; that is, the equilibrium price of Mexican goods had risen.

"The Mexicans were justifiably proud of the progress they had made in bringing down inflation, by means of the exchange rate link to the dollar, and did not want to lose it. I suspect they thought they were in a new world, as a result of the economic liberalization and NAFTA." Economist Jeffrey Frankel, Statement to the U.S. Senate Committee on Banking, Housing and Urban Affairs, March 9, 1995.

Also, there was very little pressure on the peso before March 1994, indicating that the markets did not believe that the peso was overvalued. In fact, the Bank of 


\section{Mexican Consumption, Savings, Output, and Inflation}

\begin{tabular}{|c|c|c|c|c|c|c|c|c|}
\hline & 1987 & 1988 & 1989 & 1990 & 1991 & 1992 & 1993 & 1994 \\
\hline Total Consumption* & 89.3 & 91.4 & 90.5 & 89.2 & 90.7 & 92.8 & 93.5 & 95.9 \\
\hline Private Consumption & 78.8 & 81.3 & 80.8 & 79.8 & 80.6 & 81.4 & 81.2 & 82.3 \\
\hline Public Consumption & 10.5 & 10.1 & 9.7 & 9.5 & 10.1 & 11.4 & 12.3 & 13.6 \\
\hline Total Saving* & 10.7 & 8.6 & 9.5 & 10.8 & 9.3 & 7.2 & 6.5 & 4.1 \\
\hline Private Saving & NA & 7.8 & 7.5 & 6.6 & 5.1 & 3.8 & NA & NA \\
\hline Public Saving & NA & 0.8 & 2.0 & 4.2 & 4.2 & 3.5 & NA & NA \\
\hline Real GDP Growth & 0.0 & 1.3 & 3.3 & -0.9 & 9.3 & 2.8 & 0.4 & 3.8 \\
\hline Inflation (CPI) & 159.2 & 51.7 & 19.7 & 29.9 & 18.8 & 11.9 & 8.0 & 7.1 \\
\hline
\end{tabular}

Mexico had to intervene in the market to sell pesos/buy dollars to keep the value of the peso down in January 1994, accumulating foreign exchange reserves. Figure 3 shows this accumulation as the spike upwards in foreign exchange reserves at the beginning of 1994.

Finally, a fundamental measure of whether the real exchange rate is properly valued is its effect on exports. The Mexican government questioned how the real exchange rate could be overvalued when export growth was as strong as it was. Cumulative nonoil export growth from 1985 to 1994 was more than 200 percent, in the same range as such export powers as Hong Kong, Korea, Singapore, and Taiwan. ${ }^{9}$

To summarize: Dornbusch and Werner presented evidence that the real exchange rate, as measured by the W PI, was overvalued in 1993 and 1994. Although in retrospect it looks as if Dornbusch and Werner were correct, this was not obvious at the time. Other measures of the exchange rate showed no overvaluation, economic reform had likely made historical measures less reliable than usual, and export growth was strong.

Disinflation and the Overvalued Peso. In 1993 and 1994 many economists who supported NAFTA warned that the real exchange rate had become overvalued and could lead to a crisis. ${ }^{10}$ These economists argued that the peso had become overvalued because M exican officials had used the pegged exchange rate to hel $p$ bring inflation down (see Table 1) from 159 percent in 1987 to 8.0 percent in 1993. This section explains the role of a pegged exchange rate in bringing down inflation and the dangers of such a policy.

To understand how the value of the peso affects inflation, consider how monetary policy, exchange rates, and prices interact. Because only the Bank of M exico, M exico's central bank, can issue peso currency or reserves, within very broad limits, it can control the value of the peso by controlling the supply of pesos. Similarly, the Bank of Mexico also controls M exican inflation by increasing or decreasing the growth of the money supply. No central bank, however, can independently control both the exchange rate and inflation at the same time. The desired inflation rate may not be compatible with the preferred exchange rate. That is, if a central bank picks a level of inflation to target, it must choose the particular path for the exchange rate that is consistent with that inflation rate. By choosing a path for the exchange rate (and money growth) consistent with a low inflation rate, the Bank of Mexico could use a pegged exchange rate as a tool to help lower the inflation rate.
${ }^{9}$ Data taken from Gil-Diaz and Carstens (1995).

${ }^{10}$ See Dornbusch and Werner (1994) and Hufbauer and Schott (1993). 
There are three ways in which a pegged exchange rate policy helped the fight against inflation. First, a stronger peso forced M exican producers of tradeable goods to restrain price increases to directly compete with foreign producers. Second, in every disinflation, the credibility of the disinflation is important to breaking the momentum of the inflation with little cost in lost output. That is, people have to be convinced that inflation will fall. A pegged exchange rate helps break inflationary expectations by providing a concrete measure of the progress in fighting inflation; it gives the public an inflation-sensitive nominal anchor. People can see that the currency doesn't free fall against a (low inflation) foreign currency and so they come to believe that inflation is falling. Third, maintaining the exchange rate against the dollar gives the monetary authority instant feedback as to the pressure on the value of the peso.

The danger with using a pegged exchange rate to fight inflation is that the real exchange rate will become overvalued if domestic inflation exceeds the rate of depreciation of the domestic currency plus foreign inflation. Pegging the nominal exchange rate while domestic inflation exceeds foreign inflation raises the real exchange rate, and domestic goods become more expensive in terms of foreign goods. This fights domestic inflation for the reasons outlined previously, but at the cost of making domestic industries less competitive in tradeable goods. Such a situation may quickly become unsustainable.

Despite this danger, many developing countries with histories of high inflation have used restrictive monetary policy with a pegged (or crawling peg) exchange rate to control inflation. That is the course M exico chose; from 1988 to 1994, the Bank of Mexico used the exchange rate as an instrument to bring down inflation. The peso was pegged to the dollar in March 1988. In January 1989, the peg was changed to a crawling peg and a moving target zone was introduced in December 1991. ${ }^{11}$ The lower limit of the target zone or band was lowered (devalued) only slowly. The principle of controlling the exchange rate to restrain inflation remained the same, however.

As the preceding section concluded, it was not obvious that the peso was overvalued. To the extent that it may have been, however, creating an overvalued exchange rate by using a pegged exchange rate to bring down inflation is neither new nor unique to Mexico. Numerous authors, including Corbo and De Melo (1987), have commented on the tendency toward overvaluation in the so-called "Southern Cone" countries of Argentina, Chile and Uruguay when the exchange rate is used as an instrument to reduce inflation. Gil-Diaz and Carstens (1995) add Brazil and Finland to this list of countries that experienced overvaluation. In all of these countries, there was substantial real overvaluation but no free trade agreement to blame for it.

Other Reasons to Avoid D evaluation. Velasco (1995) discusses several reasons why the M exican authorities wished to avoid devaluation in 1994. First, they did not wish to lose the gains they had made against inflation. Aside from the domestic consequences of loss of control of inflation, the M exican authorities feared that a devaluation would be ineffective in changing the rel ative price of M exican and foreign goods if inflation would outpace the depreciation of the peso. Such a devaluation would have been the worst of both worlds: more inflation, a loss of credibility and no improvement in the competitiveness of domestic goods. Further, to maintain their credibility with investors, the M exican policymakers were reluctant to devalue even in the face of large shocks. They were concerned that devaluation would call into question the policymakers' commitment to other reforms and result in a loss of foreign investment.

Summary on the Value of the Peso. In 1993-1994 Dornbusch and Werner presented evidence, convincing in retrospect, that the peso was overvalued. It was not clear at the time, however, that this was the 
case. To the extent the peso may have been overvalued, it was because of the disinflation strategy pursued by M exico, and other policy concerns. The evidence is not consistent with the claim that the government of M exico deli iberately manipulated the value of the peso and planned a devaluation years in advance or that the authorities avoided a faster rate of depreciation sol ely (or primarily) because of the politics of NAFTA.

\section{NAFTA AND \\ INTERNATIONAL CAPITAL FLOWS}

This section introduces the concept of capital flows, lays out the hypothesis that NAFTA was responsible for the peso crisis by stimulating capital flows out of M exico, and then shows that the evidence is not consistent with this hypothesis.

\section{What Are Capital Flows?}

Capital flows entail the buying and selling of existing assets. When foreign investors buy real or financial Mexican assets, for example, capital flows into M exico. Real assets include factories and real estate; financial assets encompass bonds and equity. Foreign investment is divided into foreign direct investment (FDI) and portfolio investment. FDI is distinguished from portfolio investment by active control of the assets: Buying a factory is FDI, buying a bond is portfolio investment.

The national income accounts measure net capital flows by the balance in the capital account. A surplus in a nation's capital account means that more capital is flowing into the country than is flowing out; that is, the country is selling more existing assets than it is buying. Similarly, the current account measures trade in goods and services, net receipts on foreign investment, and unilateral transfers. A current account deficit means that a country is importing more newly produced goods and services than it exports.

Aside from measurement errors, the current account balance must be equal and
Figure 4

\section{Current Account and Capital Account Balances as a Percentage of GDP}

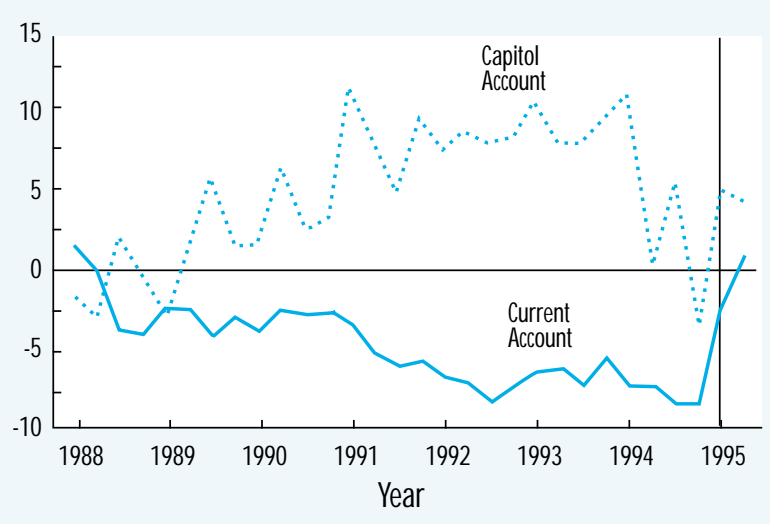

opposite to the capital account balance because a country can import more than it exports only by selling foreigners claims on existing real or financial assets. ${ }^{12}$ Thus a deficit in the current account must be balanced by an equal and opposite capital account surplus because the two accounts are the opposite sides of the same transaction. One measures the net value of the goods and services received, and the other measures the net value of the assets exchanged for the goods and services. A nation that runs a current account deficit (and, by definition, a capital account surplus) is borrowing from abroad, selling assets like bonds in exchange for new goods and services. A country running a current account surplus is lending to other countries by buying assets in exchange for exports of goods and services. In a world with balanced trade, there would be no opportunities for net international borrowing, and domestic savings would have to equal domestic investment.

Figure 4 illustrates that Mexico ran increasing current account deficits and capital account surpluses for the period 1990-1994. In other words, it was increasingly borrowing from abroad-as much as 8 percent of its GDP by 1993. Capital inflows-a capital account surplus- are useful because they permit a nation to consume more and grow faster by borrowing
${ }^{12}$ The accumulation or loss of official reserves like foreign exchange, gold, or other assets permits an exception to the rule that the current and capital accounts must balance. A nation can temporarily finance a current account deficit by selling off official assets, as Mexico did in 1994. This simply amounts to a change in the way that the capital account is defined. 
against future income. The sustainability of capital inflows (borrowing) is limited by the capacity of the borrower to pay back the loan. Borrowing for present consumption is not sustainable unless national income, or the capacity to pay back the loan, grows rapidly. Borrowing to invest in productive capacity, borrowing that increases future income or reduces future expenditures is more likely to be sustainable. Judging whether capital flows are sustainable is difficult, however, because consumption and investment are defined and measured imperfectly. For example, spending on education, health care, or consumer durables is counted in the national accounts as consumption, but perhaps it should be called investment.

\section{The Case that NAFTA Was \\ Responsible for Capital Flows that Caused the Peso Crisis}

The immediate precipitating factor in the Mexican peso crisis of December 1994 was the desire of investors to get their assets, especially portfolio investment, out of pesos, which they feared would be devalued, and into dollars or other foreign currency. That is, capital was flowing out of Mexico. This section lays out the logic behind the critics' second hypothesis about NAFTA and the Mexican financial crisis- that NAFTA drove international capital flows that led to the devaluation of the peso. There are also two versions of this hypothesis. The first version requires only that NAFTA simply encouraged capital inflows- either by depressing national savings or by making M exico a more attractive investment environmentand that capital inflows, in the form of portfolio investment, are inherently dangerous. The second version suggests that NAFTA generated political instability that sparked capital outflows and the devaluation. These hypotheses require that:

1. Either NAFTA encouraged international capital inflows, which are intrinsically destabilizing, or
2. NAFTA triggered capital outflows that led to the peso's devaluation by creating political instability.

The $C$ ase that NAFTA Generated C apital Inflows. The capital inflows to M exico (Mexico's capital account surplus) in 1990-1994 meant that Mexico was borrowing from abroad to finance its current account deficit. A low savings rate made Mexico more dependent on international capital flows and therefore more vulnerable to shocks. ${ }^{13}$ Critics contend that this dependence was critically worsened by passage of NAFTA. There are two ways in which NAFTA might generate capital inflows to M exico. The first is by decreasing Mexican national savings. The second is by increasing the desirability of investment in Mexico.

Why might NAFTA reduce Mexico's savings rate? First, by directly lowering trade barriers, NAFTA made consumption of imports, especially consumer durables, cheaper and more attractive relative to saving. Given M exico's history of protectionism, consumers may have feared that free trade was temporary and wished to buy while they could. A rise in the consumption rate must lower the savings rate because all disposable income of a nation or an individual can be classified as either consumption or savings. Second, NAFTA and other economic reforms may have increased expectations of future income, increasing M exicans' willingness to go into debt and lenders willingness to permit this. ${ }^{14}$ At the same time, financial reforms gave ordinary people greater access to credit markets and thus greater ability to go into debt. Finally, if NAFTA contributed to an artificially higher real value of the peso, that would have also made imported goods much less expensive and consumption more attractive.

“... NAFTA served as a kind of 'Good Housekeeping Seal of Approval' that encouraged even more investors into M exico."

Anderson, Cavanagh and Ranney (1996), p. 3. 
The second form of the capital inflow hypothesis suggests that NAFTA may have generated capital inflows to M exico by making M exico a more attractive investment environment. This hypothesis would explain the surge, in early 1994, of capital inflows that caused the peso to appreciate. NAFTA was considered especially important to investors because an international treaty made the reforms more likely to be permanent. There is consi derable reluctance to break a treaty with a foreign government.

An implicit assumption of the hypothesis that NAFTA was responsible for the peso crisis because it encouraged capital inflows is that such flows are inherently destabilizing. Portfolio investment, in particular, was frequently maligned as being a cause of the crisis. It was said to be moved on a whim with a short-term investment horizon, creating financial market volatility. Such a view requires that international capital markets be subject to fads or speculative bubbles. Critics point to the volatility of the dollar in the 1980s, theEuropean Exchange Rate M echanism crises of 1992 and 1993, and the recent flood of capital into emerging markets as evidence of this.

The $C$ ase that NAFTA Contributed to Capital Outflows Through Political Instability.

From the Mexican view, the purpose of NAFTA was to create a more prosperous and stable M exico. N evertheless, even good economic policy can unintentionally create dislocations and political instability. Some have charged that NAFTA contributed to the Chiapas uprising that triggered the capital outflows that brought down the peso.

"On January 1, 1994-the day that the North American FreeTrade Agreement (NAFTA) took effect, binding Mexico's modernizing economy to that of the United States-Indian peasants at the southern end of the country rose in armed rebellion. ... Many in Chiapas fear that NAFTA will worsen the existing divide be- tween Mexico's prosperous north and an impoverished south."

The Economist, January 8, 1994.

The uprising was soon contained by the Mexican army, but it and other political shocks concerned investors throughout the year. They engendered fears that the economic reforms in Mexico had moved too fast and would lead to social unrest that would roll back the reforms. In fact, the initial devaluation on December 20, 1994, was sparked by a run on the peso started by rumors of renewed fighting in Chiapas. ${ }^{15}$

These political shocks led investors to exchange pesos for dollars at the Bank of M exico, causing a series of falls in M exico's foreign exchange reserves, limiting its short-term ability to defend the peso. ${ }^{16} \mathrm{Fig}$ ure 3 illustrates the stepwise falls in foreign exchange reserves during 1994. By the time that rumors of renewed fighting rattled the markets on December 19, 1994, the Bank of Mexico had nearly run out of foreign exchange reserves. Without foreign exchange to defend the peso, the Bank of M exico had to devalue. ${ }^{17}$ Critics of NAFTA might argue that the treaty caused the peso crisis by sparking the Chiapas uprising.

\section{Evaluating the Evidence on NAFTA and Capital Flows}

This section evaluates the evidence on NAFTA and capital flows to see whether it is consistent with either of the hypotheses that NAFTA caused the peso crisis through its effect on capital flows. The first subsection examines the evidence on the extent to which NAFTA encouraged capital inflows and the next looks at the argument that capital flows are inherently destabilizing. Finally, the role of NAFTA in the Chiapas uprising and political instability is appraised.

Evidence on NAFTA and Capital Inflows. $M$ exico did indeed have low and falling national savings rates -4 percent of GDP in 1994, for example (see Table 1) - making it more dependent on international capital flows. Net savings fell from 10.8 percent of
${ }^{15}$ See Gil-Diaz and Carstens (1995) or IMF (1995) for the details of the decision to devalue.

${ }^{16}$ In the long run, the Bank of Mexico used its control over the money supply to determine the foreign exchange value of the peso. Over the short term, however, the Bank of Mexico defended the value of the peso by buying and selling pesos for dollars. By itself, this action would reduce the supply of pesos and push up Mexican interest rates. The Bank of Mexico, however, fully sterilized the purchase of pesos by buying outstanding bonds in $\mathrm{ex}$ change for pesos, putting the pesos back into circulation. Sterilization is intended to leave domestic interest rates unchanged after foreign exchange purchases or sales.

${ }^{17}$ Some suggest that the Bank of Mexico could have used its control over the domestic money supply to defend the peso, but it was reluctant to do this because of the effect high interest rates would have had on the real economy and the banking sector. Certainly by December 1994 this strategy would have imposed large costs. 
GDP in 1990 to 4.1 percent of GDP in 1994. ${ }^{18}$ This reduction in savings was driven by corresponding increases in private and government consumption, which rose 2.5 percentage points and 4.1 percentage points, respectively, over the same period.

There are several problems with the hypothesis that the declining savings was a result of NAFTA. First, it is not very plausible that NAFTA would cause a large rise in private (or government) consumption. Trade barriers cause consumers to substitute one form or source of consumption for another but change aggregate levels of consumption/saving relatively little. Thus the effect of trade liberalization on trade deficits is not likely to be very big. Also, the fact that most of the increase in consumption was caused by a rise in government consumption does not fit well with the hypothesis that NAFTA caused the fall in savings. The sluggish economy in 1993 and election year politics in 1994 were more likely than NAFTA to have played a role in this relaxation of fiscal policy. Finally, the timing of the inflows is wrong; the inflows started in 1990 with the resolution of the debt crisis and the liberalization of capital account rules to permit foreigners to hold government bonds and nonvoting equity shares in M exican firms. ${ }^{19}$ Figure 4 illustrates this rise in the capital account surplus; the majority of capital inflows had entered Mexico well before NAFTA was negotiated, much less enacted. Other economic reforms, like the decline in inflation and the privatization of state-owned industries, also helped drive investment.

While NAFTA was not the only or even the major causal factor for capital inflows, it probably had some marginal effect. Figure 4 shows that M exico's capital account surplus did peak in the first quarter of 1994, coinciding with the implementation of NAFTA. The figure is somewhat deceptive in that a surge in inflows in January 1994 and February 1994 was masked in the quarterly capital account figures by a major outflow in $M$ arch after the assassination of presidential candidate Luis Donaldo Colosio.
Part of the capital inflow was soaked up in the form of a rapid increase and then decrease in official reserves-shown by the spike in Figure 3 at the beginning of 1994. That is, the Bank of Mexico bought up dollars in sterilized intervention to keep the price of the peso down in January and February 1994. The surge was not out of proportion to earlier flows, however.

To the extent that private Mexican consumption increased in the early 1990s, there are many factors aside from NAFTA to explain it. Prolonged slow growth (since 1980) had created repressed consumer demand. After growth returned in 1988, consumption spending rose along with it. Also, to the limited extent that reducing trade barriers may change savings and consumption decisions, NAFTA was not the only trade initiative. Mexico engaged in unilateral trade liberalization and trade agreements with Chile, Colombia, Venezuela, and Costa Rica. Similar to other developing countries, economic reform and financial liberalization-quite apart from NAFTA - raised expectations of increased future income and gave more Mexicans access to credit.

To summarize: the evidence does not support the argument that NAFTA drove large capital inflows to Mexico. NAFTA did increase foreign confidence and marginally increased capital inflows, but most capital inflows had entered before passage of NAFTA. In fact, NAFTA may have delayed a crisis by drawing in capital that supported the peso in early 1994.

Volatility of Capital Flows. The question of whether capital flows are excessively volatile or inherently destabilizing is difficult to answer because capital should exit a country in response to poor economic policies or other factors that reduce its productivity. This hel ps ensure that capital is as productive as possible and provides governments with an immediate incentive to maintain sound policies. On the other hand, it is possible that portfolio investment overreacts to information, and this volatility does create problems.
${ }^{19}$ See Sachs, Tornell and Velasco (1995a and 1995b). 
Because capital does move rapidly out of weak currencies in moments of crisis and these movements can be destabilizing, some economists have advocated a very small tax on international financial transactions to deter short-term speculation. ${ }^{20}$ Trying to eliminate international capital flows would be a mistake, however, because capital inflows can be quite helpful in promoting development. Also, they are not necessarily destabilizing. Rather, their volatility can depend on the soundness of macroeconomic policies followed in the recipient countries. Further, outflows occur without regard to the nationality of the investors in the presence of unsound macroeconomic policies. Domestic residents would get their money out of the domestic assets under the same conditions as international investors, if the value of these assets were threatened.

\section{NAFTA and the Chiapas Uprising.}

NAFTA may have been a catalyst for, but certainly was not the cause of, the Chiapas uprising. This rebellion reflected grievances long and deeply felt by the impoverished south against the more prosperous north. Also, the uprising was only one political shock among many that M exico endured that year, including two major assassinations, a rise in U.S. interest rates and a presidential election. If the December Chiapas uprising had not sparked the crisis, something else likely would have.

Capital Flows to Emerging Markets. Mexico is not the only developing country to experience heavy capital inflows recently. In the last 10 years capital inflows to developing countries have increased sharply because of two factors: market-oriented policy reforms and low interest rates prevailing in the developed world. These factors draw in capital because policy reforms raise the return to investment in developing countries and the low interest rates in the developed world provide a less attractive al ternative for international investors. For developing countries, capital flows provide a much needed source of funds for economic growth. Ideally, international capital flows provide major advantages for both investors and recipients.

This movement of assets can also cause difficulties, however. Corbo and Hernandez (1996) studied the problems posed by this movement of assets in nine countries: Argentina, Chile, Columbia, Indonesia, Malaysia, M exico, the Philippines, South Korea, and Thailand. They report that though the absolute level of investment in Mexico from 1986 to 1993 was very large compared with the other countries, Thailand, Malaysia, and Chile received larger capital inflows as a percentage of GDP than did Mexico. Many of these countries have also encountered problems similar to those confronted by the Mexican authorities. For example, in regimes with fixed or predetermined exchange rates, capital inflows can lower domestic interest rates, raise domestic expenditures and temporarily raise inflation, which can lead to an overvalued currency and large trade deficits.

Partly to offset the tendency toward overvaluation caused by the capital flows, all of these countries have undertaken liberalization of trade, though none of them has concluded a trade agreement comparable in importance to NAFTA. But free trade agreements are not necessary to create substantial capital inflows. The breadth and size of these capital flows to reforming countries in the developing world in the last 10 years makes it difficult to believe that NAFTA was the primary reason for the inflows to Mexico.

Capital flow volatility poses particular problems for fixed exchange rate regimes because capital outflows are synonymous with exchange rate crises. Investors who perceive a possibility of a discrete fall in the value of their assets (that is, a devaluation), will attempt to get their money out of the weak currency. Thus crises appear suddenly when capital is easily moved. These outflows are merely a symptom of the problem, however, not the cause.

Summary of the Evidence on NAFTA and Capital Flows. NAFTA is an unlikely culprit to blame for the quantity of capital in-
${ }^{20}$ See Frankel (1996) for a short discussion of the Tobin tax. 
flows M exico received in the early 1990s. The surge in capital flows started well before the enactment of NAFTA and had more to do with the rise in consumption by the Mexican government and the other economic reforms undertaken.

Whatever the source or timing of the inflows, however, NAFTA was not responsible for the outflows. It is generally acknowledged that the outflows were generated by some combination of inconsistent policies and political shocks that generated a liquidity crisis; the Mexican government had more short-term obligations-in the form of dollar-linked bonds-coming due than it had liquid assets. ${ }^{21}$

\section{CONCLUSION}

As Mexico entered into NAFTA at the beginning of 1994, it was widely and correctly applauded as a model of economic reform. Before the end of the year, however, it was forced to first devalue and later to allow the peso to float. In early 1995, it was forced to borrow from the IMF and the United States to get through a liquidity crisis.

Critics of NAFTA such as Ross Perot,

${ }^{21}$ Because the Bank of Mexico had ultimate control over the supply of pesos, it is true, by definition, that the devaluation was caused by insufficiently tight monetary policy. That is, the Mexican authorities' exchange rate and growth policy objectives were mutually inconsistent. For a discussion of the policy priorities of the Mexican authorities, see Gruben (1996) or Gil-Diaz and Carstens (1995). Overviews of the events leading to the crisis may be found in OECD (1995), IMF (1995) or GAO (1996). Calvo (1996) and Garber and Lall (1996) discuss the roles played by capital flows and weakness in the Mexican financial system. Sachs, Tomell and Velasco (1995a and 1995b) discuss the problems created by Mexico's dollar-linked debt instruments. the peso because of NAFTA and that NAFTA caused volatile international capital flows that brought down the peso. The evidence does not support the hypothesis that the crisis could have resulted from NAFTA's economic effects. Any peso overvaluation in 1994 resulted from the use of the exchange rate to reduce inflation, a common consequence of this strategy. Although capital inflows can present problems and aggravate instability in developing countries, they are also very useful to promote economic development. In any case, the flows to Mexico were only partially driven by NAFTA. NAFTA was not, in any sense, responsible for the devaluation, but this episode reminds us that good policies can have unintended consequences.

\section{REFEREN CES}

Aguilar, Linda M. "NAFTA: A Review of the Issues," Federal Reserve Bank of Chicago Economic Perspectives (Jan/ Feb 1993), pp. $12-20$.

Anderson, Sarah, John Cavanagh and David Ranney, eds. NAFTA's First Two Years- The Myths and the Realities. Washington D.C.: The Institute for Policy Studies, 1996.

Brown, Drusilla K., Alan V. Deardorf and Robert M. Stem. "A North American Free Trade Agreement: Analytical Issues and a Computational Assessment," The World Economy (January 1992), pp. 11- 29.

Calvo, Guillermo. "Capital Flows and Macroeconomic Management: Tequila Lessons," unpublished manuscript (March 1996).

Corbo, Vittorio, and Jaime de Melo. "Lessons from the Southem Cone Policy Reforms," World Bank Research Observer (July 1987), pp. 111- 42.

, and Leonardo Hernandez. "Macroeconomic Adjustment to Capital Inflows: Lessons from Recent Latin American and East Asian Experience." World Bank Research Observer (February 1996), pp. 61- 85.

Dornbusch, Rudiger, and Alejandro Werner. "Mexico: Stabilization, Reform and No Growth," Brookings Papers on Economic Activity, vol. 1, (1994), pp. 253- 97.

Freidman, Mitton. "A Theory of the Consumption Function." Princeton University Press, 1957.

Garber, Peter M., and Subir Lall. "The Role and Operation of Derivative Markets in Foreign Exchange Market Crises," unpublished manuscript (February 1996).

Gil-Diaz, Francisco, and Agustin Carstens. "One Year of Solitude: Some Pilgrim Tales About Mexico's 1994-1995 Crisis," The American Economic Review (May 1996), pp. 164- 9.
, and _. _ . "Some Hypotheses Related to the Mexican 1994-1995 Crisis," Banco de Mexico, Serie Documentos de Investigacion (1995) 9601

Greider, William. "Southern Comfort. How Come There Are Billions to Bail Out Mexico But Nada for U.S. Cities?" Rolling Stone (March 9 1995), pp. 40- 2.

Gruben, William C. "Policy Priorities and the Mexican Exchange Rate Crisis," Federal Reserve Bank of Dallas Economic Review (First Quarter 1996), pp. 19-29.

Hufbauer, Gary Clyde, and Jeffrey J. Schott. NAFTA: An Assessment. Institute for International Economics, 1993.

International Monetary Fund. "Evolution of the Mexican Crisis," in International Capital Markets. Developments, Prospects, and Policy Issues, IMF (1995), pp. 53-69.

Kehoe, Timothy J. "A Review of Mexico's Trade Policy from 1982 to 1994," The World Economy: Global Trade Policy (1995), pp. $135-51$. 
Krugman, Paul. "Review of: NAFTA: An assessment," Joumal of Economic Literature (J une 1995), pp. 849- 51.

_. . . . "The Uncomfortable Truth about NAFTA: Its Foreign Policy, Stupid," Foreign Affairs (Nov.Dec. 1993), pp. 13- 19.

Kuttner, Robert. "Trouble in Mexico no surprise, misguided NAFTA leads to drop in peso," Akron Beacon Journal (January 22, 1995),

p. Cl.

"Mexico's second-class citizens say enough is enough," The Economist (January 8, 1994), pp. 41 - 3.

Organization for Economic Co-operation and Development. OECD ECOnomic Surveys 1994-1995, Mexico (1995).

Oliver, Christian. Conference Summany of "Did NAFTA Kill the Peso?" American Enterprise Institute for Public Policy Research, January 30, 1996.

Orme, William. "Myths versus Facts: The Whole Truth about the HalfTruths," Foreign Affairs (Nov.-Dec. 1993), pp. 2- 12.

Perot, Ross. "Perspective on NAFTA," Los Angeles Times (January 4, 1995), p. 7.

Rowen, Hobart. "Administration Ignored Peso Warnings," The Washington Post (February 5, 1995), p. H2.

Sachs, Jeffrey, Aaron Tornell and Andres Velasco. "The Collapse of the Mexican Peso: What Have We Learned?" National Bureau of Economic Research Working Paper (June 1995a), 5142.

_. . . The Real Story," The International Economy (March/ April 1995b), pp. 14- 17 and 50- 1.

Schott, Jeffrey J. "NAFTA: An American Perspective," Intemational Trade Joumal (Spring 1994), pp. 3-8.

Tornell, Aaron, and Gerardo Esquivel. "The Political Economy of Mexico's Entry to NAFTA," National Bureau of Economic Research Working Paper (October 1995), 5322.

United States General Accounting Office (GAO). "Mexico's Financial Crisis. Origins, Awareness, Assistance, and Initial Efforts to Recover." Report to the Chairman, Committee on Banking and Financial Services, House of Representatives, February 1996.

United States Senate. "The Mexican Peso Crisis," Hearings before the Committee on Banking, Housing, and Urban Affairs (Jan. 31, 1995, March 9-10, May 24, 1995, and July 14, 1995).

Velasco, Andres. "Lessons from the Recent Mexican Crisis," CV Starr Newsletter (vol. 13, 1995). 